\title{
THE RELEASE OF SODIUM DICLOFENAC FROM MATRIX TYPE OF TRANSDERMAL PATCH
}

\author{
Aditya Fridayanti ${ }^{1)}$, Esti Hendradi ${ }^{2}$, Isnaeni ${ }^{3)}$ \\ Kelompok Bidang Ilmu Farmasetika, UP. Fakultas Farmasi, Universitas Mulawarman, Samarinda \\ e-mail:dietya_fy@yahoo.com ${ }^{1)}$ \\ Departemen Farmasetika, Fakultas Farmasi, Universitas Airlangga,, Surabaya ${ }^{2)}$ \\ Departemen Kimia Farmasi, Fakultas Farmasi, Universitas Airlangga, Surabaya ${ }^{3)}$
}

\begin{abstract}
ABSTRAK
Pelepasan natrium diklofenak dari Sediaan Transdermal Patch Tipe Matriks dengan kombinasi polimer etil selulosa (EC) N-20 dan polivinilpirolidon (PVP) K-30 telah diteliti. Pada penelitian ini sediaan transdermal patch tipe matriks yang mengandung natrium diklofenak dibuat dengan kombinasi polimer etil selulosa (EC) N-20 dan polivinilpirolidon (PVP) K-30 pada perbandingan yang berbeda ( 9:1 (Formula I); 8:2 (Formula II); dan 7:3 (Formula III)). Persentase (\%) moisture content dihitung dari perbedaan berat relatif pada penimbangan akhir. Uji homogenitas permukaan patch dilakukan dengan menggunakan metode Scanning Electron Microscopy (SEM). Uji disolusi dengan media larutan dapar fosfat salin pH 7,4 \pm 0.05 sebanyak 500,0 mL yang terlebih dahulu dipanaskan sampai mencapai temperatur percobaan $37 \pm 0.5^{\circ} \mathrm{C}$ diaduk pada kecepatan $50 \mathrm{rpm}$. Hasil dianalisis menggunakan SPSS dengan metode ANOVA one way dengan tingkat kepercayaan 95\% ( $\alpha=$ 0,05). Berdasarkan penelitian ini, penggunaan polimer kombinasi antara etil selulosa (EC) $N$ 20 dan polivinilpirolidon ( $P V P$ ) K-30 dapat meningkatkan fluks pelepasan natrium diklofenak dari sediaan patch natrium diklofenak. Perbandingan 7:3 dari etil selulosa (EC) N-20 dan polivinilpirolidon (PVP) K-30 adalah kombinasi yang terbaik untuk sediaan patch natrium diklofenak karena konsistensi bentuk fisik serta nilai fluks pelepasan dan penetrasi yang dihasilkan lebih besar dari perbandingan lainnya.
\end{abstract}

Kata Kunci : Pelepasan Sodium diklofenak, plasticizer, kombinasi matrix dari EC N-20 dan PVP K-30

\begin{abstract}
The sodium diclofenac realeased from transdermal patch of combination of ethyl cellulose (EC) N-20 and polyvinyl pyrollidon (PVP) K-30 was investigated. In this study, matrix-type of transdermal patch containing diclofenac sodium were prepared using polymeric combination of EC N-20 and PVP K-30 in various ratios ( 9:1 (Formula I); 8:2 (Formula II); and 7:3 (Formula III)). The percentage of moisture content was calculated as a difference between initial and final weight with respect to final weight. The homogeneity of patch surface was determined using fluorescence microscope and scanning electron microscope (SEM). Released test using dissolution apparatus were carried out in $500 \mathrm{~mL}$ of phosphate buffer saline $\mathrm{pH} 7.4 \pm 0.05$ at temperature $37 \pm 0.5^{\circ} \mathrm{C}$ with speed of swirl $50 \mathrm{rpm}$. Results were analyzed by statistic programmed of SPSS using one way analysis of variance with degree of believed $95 \%(\alpha=0,05)$. It can be concluded that the combination of EC N-20 and
\end{abstract}


PVP K-30 at ratio 7:3 was the best choice for manufacturing transdermal patch based on physicochemical and the release profile.

Keywords: Diclofenac sodium released, plasticizer, combination matrix of EC N-20 and PVP K-30

\section{INTRODUCTION}

These last few years, the transdermal route has become one of the most successful and innovative focus for research in drug delivery. One dosage form is provided by transdermal patch dosage forms. Patch is a dosage form that aims to transport drugs through the skin into the blood circle [1]. Patch will be effective when the drug must obviously be able to penetrate into the skin barrier and reach the target [2]. Criteria these are typically used for selection include parenteral dose less than 20 $\mathrm{mg} /$ day, short half-life (requiring multiple daily doses in current dosage form), acceptable skin toxicity (little or no skin irritation or sensitization), molecular weight less than 500 Daltons, log octanolwater partition coefficient of approximately 0-3 and solubility in mineral oil and water greater than $1 \mathrm{mg} / \mathrm{mL}^{3}$.

Some of the drug when given in oral form, drugs undergoes substansial hepatic firstpass metabolism and give side effects such as irritation of the stomach, so better if given in the patch dosage form [3]. Patch preferred over intravenous administration for not causing pain, tissue damage and removes the fear of patients [3].

Sodium diclofenac is reported used for topical applications. The drug undergoes substansial hepatic first-pass metabolism and only $50 \%$ of administered dose reaches systemic circulation [4].
The aim of the present study is to know how the influence of a combination of ethyl cellulose polymer and polyvinylpyrrolidone in the ratio 9:1, 8:2 and 7:3 in increasing the flux of diclofenac sodium release from matrix $100 \mathrm{mg} / 50$ $\mathrm{cm}^{2}$, added menthol as an enhancer with levels of $1 \%$ and polyethylene glycol 400 as plasticizer with levels of $20 \%$, with a method of making a matrix controlled, so as to obtain a combination of polymers with a precise comparison to diclofenac sodium dosage patch matrix type.

\section{METHOD}

\section{Material}

Sodium diclofenac (Aarti Drugs Limited), PVP K-30 (SP (Singapore) Pte Ltd), EC N22 (Dow Chemical Company), and menthol were purchased from PT Bratachem. All ingredients of these were pharmaceutical grade, alcohol $96 \%$ was analytical grade.

\section{Preparation}

Dosage sodium diclofenac patch matrix type controlled by the ratio of different polymers made planned to produce an average weight of 0.500 grams with a diameter of $3 \mathrm{~cm}$, surface area $7.065 \mathrm{~cm}^{2}$ (table 1).PVP K-30 and EC N-20, respectively - were dissolved in ethanol $96 \%$. Solution of PVP K-30 included in the solution of N-20 EC, stirring until evenly mixed. Previously menthol solution was made by dissolving 0.050 grams of menthol in ethanol $96 \%$ to $100 \mathrm{~mL}$. 
Table 1. Formula of the sodium diclofenac patch base

\begin{tabular}{ccccc}
\hline \multirow{2}{*}{ Material } & \multicolumn{4}{c}{ Concentration $\left(\mathrm{mg} / 7.065 \mathrm{~cm}^{2}\right)$} \\
\cline { 2 - 5 } & Formula 1 & Formula 2 & Formula 3 & Formula 4 \\
\hline Sodium diclofenac & $14.13 \mathrm{mg} /$ & $14.13 \mathrm{mg} /$ & $14.13 \mathrm{mg} /$ & $14.13 \mathrm{mg} /$ \\
& $7.065 \mathrm{~cm}^{2}$ & $7.065 \mathrm{~cm}^{2}$ & $7.065 \mathrm{~cm}^{2}$ & $7.065 \mathrm{~cm}^{2}$ \\
EC N-20 & 342.78 & 304.70 & 266.61 & 228.52 \\
PVP K-30 & 38.09 & 76.17 & 114.26 & 152.35 \\
Polyetylenglikol 400 & 100 & 100 & 100 & 100 \\
Menthol & 5 & 5 & 5 & 5 \\
\hline
\end{tabular}
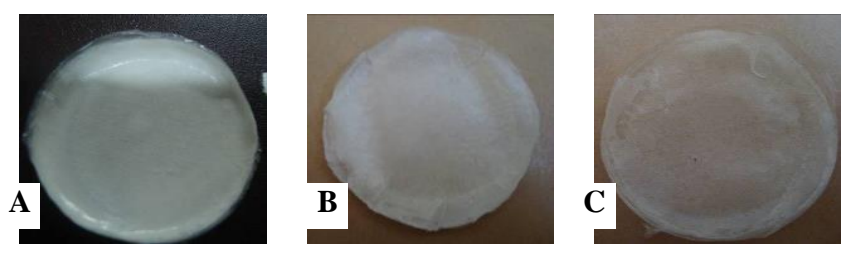

Figure 1. The results of organoleptics evaluation of the sodium diclofenac patch, $A=$ formula 9:1; $B=$ formula $8: 2$ and $C=$ formula $7: 3$

For each - each formula, $1.0 \mathrm{~mL}$ of menthol solution was poured into the sodium diclofenac, stirred until dissolved. Mixture of diclofenac sodium and menthol added to the mixture of PVP K-30 and EC N-20. Stirred carefully until all the ingredients mixed. Polyethylene glycol 400 and the remaining $96 \%$ ethanol solutions were added gradually while continue to be stirring until homogeneous. After a homogeneous preparation was poured into a mold and dried at room temperature for 24 hours.

\section{Evaluation of patches Moisture content}

The prepared flms were weighted individually and kept in a dessicator containing silica at room temperature for 24 hours. The films were weighed again and again until they showed a constant weight. The percent moisture content was calculated using the following formula: Percent moisture content $=$ (initial weight final weight/final weight) $\mathrm{x} 100$.

\section{Homogeneity of the patch surface}

Homogeneity of patch surface was analyzed using a fluorescence microscope and a scanning electron microscope (SEM).

\section{In Vitro Release Studies}

The in vitro release of the patches was performed using USP dissolution apparatus 5-paddle over disk with completely cell diffusion.

The patches (in cell diffusion) were placed respective in the dissolution chamber. All in vitro released study were performed at $50 \mathrm{rpm}$, with each medium of dissolution (phosphate buffer saline $\mathrm{pH} 7.4 \pm 0.05$ at temperature $37 \pm 0.5^{\circ} \mathrm{C}$ ) was $500 \mathrm{~mL}$. The samples withdrawn at different time intervals were analyzed for drug content using spectrophotometer Double Beam UV-VIS Recording UV 160 A (Shimadzu). All of the results were analyzed by statistic programmed of SPSS using one way analysis of variance with degree of believed 95\% $(\alpha=0,05)$. 
The Release of Sodium Diclofenac from Matrix Type of Transdermal Patch

Moisture Content (\%)

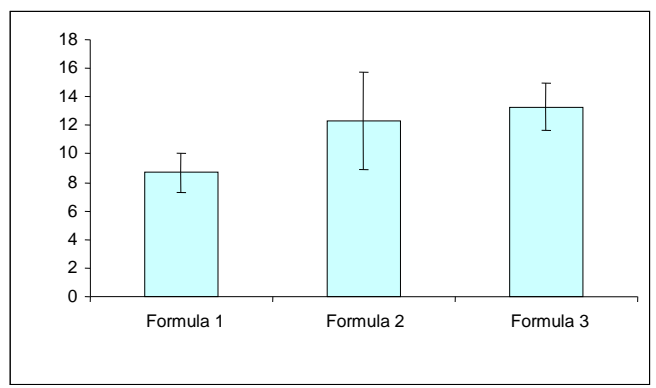

Figure 2. Histogram of the moisture content patch sodium diclofenac. Each column represents the mean \pm $S D(n=3)$.

A1 (9:1)

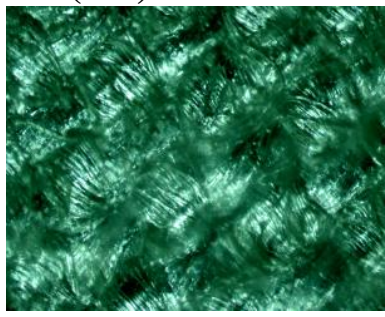

A2 (8:2)

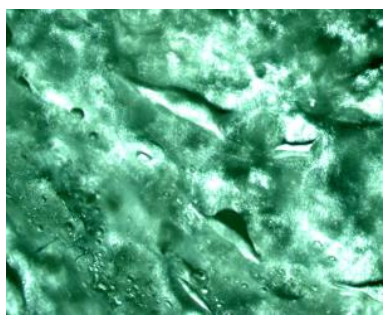

A3 (7:3)

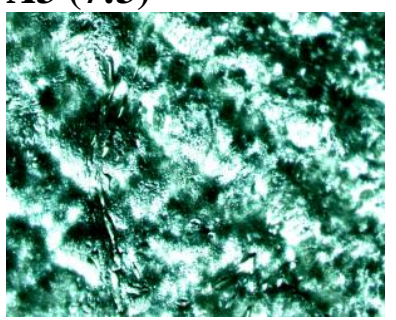

B1 (Kontrol 9:1)

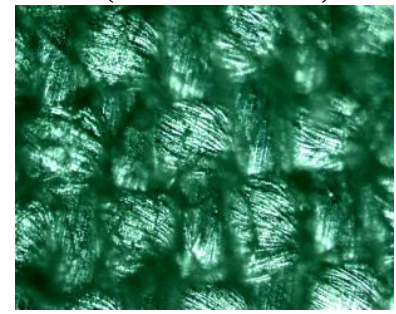

B2 (Kontrol 8:2)

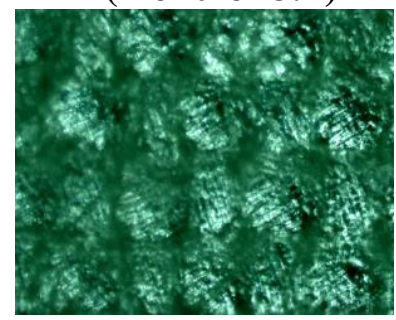

B3 (Kontrol 7:3)

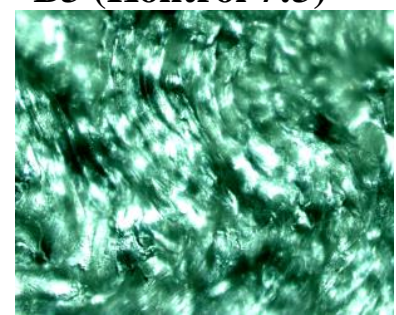

Figure 3. The results of Fluorescence microscope images of diclofenac sodium patch using electron microscope Olympus DX 41 Nokuler Three types of TF with 100x magnification. A: patch type polymer matrix with a ratio of ethyl cellulose (EC) N-20-polyvinylpyrrolidone $(P V P) K-30$ in a row is: $A 1=9: 1 ; A 2=8: 2 ; A 3=7: 3$; control patch type polymer matrix with a ratio of ethyl cellulose (EC) N-20-polyvinylpyrrolidone $(P V P) K-30$ in a row are: $B 1=9: 1 ; B 2=8: 2 ; B 3=7: 3$ 


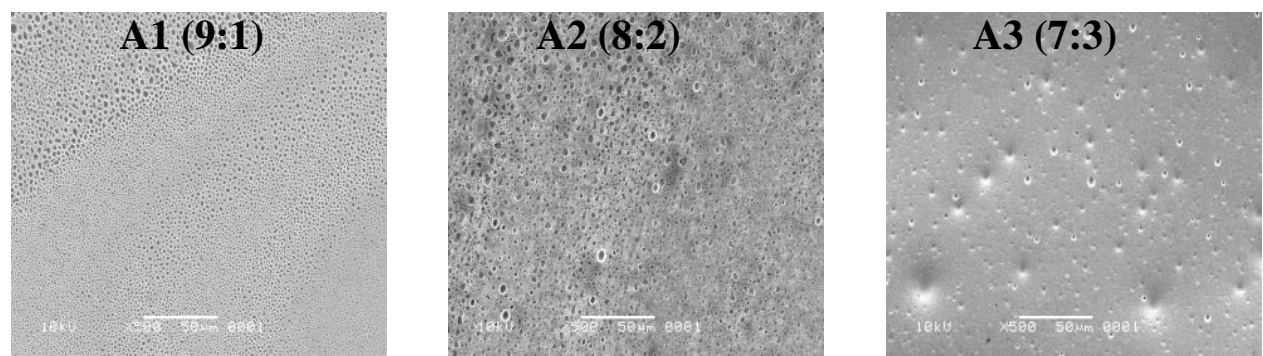

Figure 4. The results of electron microscope images of diclofenac sodium patch using Scanning Electron Microscope with (SEM) with 500x magnification. A: patch type polymer matrix with a ratio of ethyl cellulose $(E C) N$-20-polyvinylpyrrolidone $(P V P) K$-30 in a row is: $A 1=9: 1 ; A 2=8: 2 ; A 3=7: 3$

\section{RESULT AND DISCUSSION}

The results of organoleptics evaluation showed that the composition of patch formulation using combination polymer EC N-20 and PVP K-30 at ratio 9:1 and 8:2 more rigid and not easy to breaking compared with that of ratio $7: 3$ (figure1).Physicochemical parameter of the prepared formulation were evaluated in this study. The percentage moisture content of the formulation was determined (figure 2). The result of moisture content studies showed that the \%value \pm SD of moisture content from 3 replication of formula 1 was $8.67 \pm 1.33$; formula $212.30 \pm 3.42$ and formula 3 was $13.30 \pm 1.65$. The results showed with an increasing percentage of hydrophilic polymers, PVP K-30, in the formulation, moisture content increased. Fluorescence microscope and a Scanning electron microscope (SEM) study showed the surface of the sodium diclofenac matrix (figure 3 dan 4). Observations using electron microscopy at 100x magnification showing the addition of polymers PVPK30 diclofenac sodium patch causes the surface to be uneven, and this is because the formation of pores on the surface of the matrix that will assist the release of diclofenac sodium. To clarify the results observed with electron microscope photographs, images can be compared with surface patches using a scanning Electron Microscope (SEM) with 500x magnification. Results from SEM images show the formation of pores on the surface of diclofenac sodium patch. The greater the levels of polyvinylpyrrolidone (PVP) K-30, the pores formed are larger and spread out evenly across the surface of the patch.

The results of in vitro drug release are presented in figure 5 , showed the released process of sodium diclofenac from patch base. The cumulative amount of the drug released from patch base was plotted as a function root of time and a linear regression analysis was used to determine the flux of sodium diclofenac.

Figure 6 shows the flux of sodium diclofenac from the patch base. Based on the in vitro released study, the flux of diclofenac from patch base were $37.482 \pm$ $15.529 \mu \mathrm{g} / \mathrm{cm}^{2} /$ minute $^{1 / 2} ; 34.587 \pm 4.027$ $\mu \mathrm{g} / \mathrm{cm}^{2} / \mathrm{minute}^{1 / 2} ;$ and $43.540 \pm 2.555$ $\mu \mathrm{g} / \mathrm{cm}^{2} /$ minute $^{1 / 2}$ respectively for Formula I, Formula II and Formula III. The result of statistic using ANOVA one way showed that $\mathrm{F}_{\text {calculated }}(0.712)>\mathrm{F}_{\text {table }}$ (5.14). It means that there was no significant difference in increased concentration of PVP K-30 in formulation of sodium diclofenac patch. But the highest flux of piroxicam was 43.540 \pm 2.555 $\mu \mathrm{g} / \mathrm{cm}^{2} /$ minute $^{1 / 2}$ with the highest concentration of PVP K-30 and the smallest concentration of the EC N-22 between all of the formula. PVP K-30 in matrix would form pores for released sodium diclofenac. This phenomena was similar with result of the preview research 
that said with increasing the hydrophilic polymer the formed of pores in the matrix increased, so that the released of the drug increased [5].

Based on this study, the using of polymer combination between PVP K-30 and EC N22 could increase flux released of sodium diclofenac from patch base. The ratio of 7:3 for PVP K-30 and EC N-30 at Formula III was the optimal composition for base of patch sodium diclofenac type matrix with menthol as enhancer and PEG 400 as plasticizer.

\section{CONCLUSION}

The polymeric combination PVP K-30 and EC N-22 at ratio 7:3 (Formula III) was the best choice for manufacturing transdermal patch base of sodium diclofenac among the formulations studies with the highest value of flux $\left(43.540 \pm 2.555 \mu \mathrm{g} / \mathrm{cm}^{2} / \mathrm{minute}^{1 / 2}\right)$.

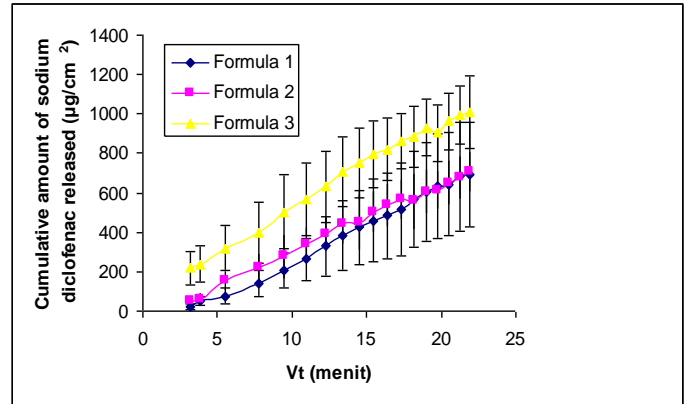

Figure 5. Profil of Sodium diclofenac released from patch bases to phosphate buffer saline solution $p H$ $7.4 \pm 0.05$ at $37 \pm 0.5^{\circ} \mathrm{C}$, with speed of swirl $50 \mathrm{rpm}$. Each column represents the mean $\pm S D(n=4)$.

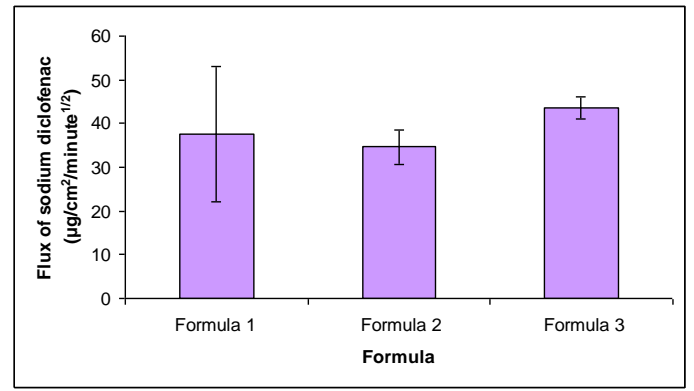

Figure 6. Histogram of the flux of Sodium diclofenac released from patch bases to phosphate buffer saline solution $p H 7.4 \pm 0.05$ at $37 \pm 0.5^{\circ} \mathrm{C}$, with speed of swirl $50 \mathrm{rpm}$. Each column represents the mean $\pm S D$ $(n=4)$.

\section{ACKNOWLEDGEMENT}

The researchers greatly acknowledge to Faculty of Pharmacy Mulawarman University for providing financial support for this research project, Pharma-Ceutical Laboratorium, Faculty of Pharmacy, Airlangga University.

\section{REFERENCES}

1. Valenta, C.; \& Auner, B.G. 2004. The Use of Polymers for Dermal and Transdermal Delivery. European J. Pharmaceutics and Biopharmaceutics, 58, 279-289

2. Kumar, R.; \& Philip, A. 2007, Modified Transdermal Technologies: Breaking the Barriers of Drug Permeation via the Skin. Tropical J. Pharma-ceutical Research, 6 (1), 633-644 
The Release of Sodium Diclofenac from Matrix Type of Transdermal Patch

3. Rathbone, M.J.; Hadgraft, J.; \& Roberts, M.S. 2002, Modified-Release Drug Delivery Technology, Marcel Dekker, Inc. New York, Basel. 471-498

4. Chuasuwan, B.; Binjesoh, V.; Polli, J.E.; Zhang, H.; Amidon, G.L.; Junginger, H.E.; Midha, K.K.; Shah, V.P.; Stavchansky, S.;
Dressman, J.B.; \& Barends, D.M. 2008, Biowaiver Monographs for Immediate Release Solid Oral Dosage Forms: Diclofenac Sodium and Diclofenac Potassium. J. Pharmaceutical Sciences.1-14

5. Utami, A.W., 2006. Skripsi, Fakultas Farmasi Unair, Surabaya. 